\title{
Seagrasses-a Tribute to Dr. Susan Williams
}

\author{
Robert J. Orth ${ }^{1} \cdot$ Ken L. Heck ${ }^{2}$ \\ Received: 12 November 2020 / Revised: 2 December 2020 / Accepted: 3 December 2020 / Published online: 11 January 2021 \\ (C) Coastal and Estuarine Research Federation 2021, corrected publication 2021
}

This special issue of Estuaries and Coasts is dedicated to Dr. Susan Williams, who, throughout her career, played a lead role in advancing seagrass ecology and mentored some of its most accomplished practitioners. Her influence, successes, and role as a teacher and mentor are detailed in the warm remembrance by Dennison (Dennison et al. 2021) that leads off this collection of papers in Susan's honor.

Seagrasses are key sentinel species whose sensitivity to changing water quality is well known to signal deteriorating conditions in coastal waters. Globally, seagrasses also face many emerging challenges associated with our changing climate. These include the effects of warming temperatures, decreasing $\mathrm{pH}$, and dissolved oxygen concentrations. In addition, the immigration and assimilation of tropical species, whose predatory, competitive, and pathological effects on the ecology of seagrasses and their associated biotas may be enormous but which remain unknown and unpredictable.

The threats faced by seagrasses coincide with the nearly five decades of great progress in understanding their biology, the ecology of the world's seagrass meadows, and the value of the many services they provide. During this time there have been paradigm shifts in our understanding of the basic biology of seagrasses and the many fundamental processes that underpin the functioning of seagrass meadows. Among them is a revised understanding of the phylogeny and evolutionary history of seagrass lineages, the smaller role played by the consumption of seagrass detritus, and the larger role of direct consumption of seagrasses. Additional advances include convincing evidence that seagrasses can be pollinated by small invertebrates, that microbial-seagrass interactions in the

Communicated by Charles Simenstad

Robert J. Orth

jjorth@vims.edu

1 Virginia Institute of Marine Science, College of William and Mary, Gloucester Point, VA 23062, USA

2 Dauphin Island Sea Lab, University of Alabama, Dauphin Island, AL 36528, USA sediments and water column are a vast area only beginning to be explored, and that individual seagrass clones can cover vast areas and exist for millennia.

We also have a better understanding of the widely varying dispersal abilities of different seagrass species, as revealed by field evidence of both short and long-distance seed dispersal, and the ability of seeds to pass through the guts of fish, turtles, birds, and sirenians, to survive, and to germinate. In addition, our ability to genotype seagrass clones is much-improved and has allowed us to better understand how different clones respond to stressors. This rapidly advancing knowledge, aided by much trial and error, has helped to improve the success of seagrass restoration efforts.

We have also seen important progress in valuing the ecosystem services provided by seagrass meadows, including their important role as nursery habitat for a variety of economically important finfish and shellfish. We now know the role small invertebrates play in plant production by removing epiphytes and their importance in top down control of seagrass health versus traditional bottom up influences. Other previously less well-known services, such as their functioning as vast reservoirs of blue carbon, are also becoming increasingly understood, with profound implications for the earth's changing climate.

The groundbreaking research carried out by Susan Williams paved the way for many of the discoveries described in the papers of this special issue and we are confident that these 19 papers are a fitting tribute to her legacy.

\section{Reference}

Dennison, W.C., M.E.S. Bracken, M. Brown, J.F. Bruno, J.T. Carlton, R.C. Carpenter, T.J.B. Carruthers, M.N. Dethier, C.M. Duarte, T.R. Fisher, J.W. Fourqurean, R.K. Grosberg, L.J. Hamdan, K.L. Heck, Jr., D.J. Howard, A.R. Hughes, B.B. Hughes, G.A. Kendrick, W.J. Kenworthy, F. Mars, C.P. McRoy, R.L. Naylor, B. Nyden, J.C. Ogden, S. Olyarnik, R.J. Orth, F.T. Short, C.J.B. Sorte, J.J. Stachowicz, D.R. Strong, C. Sur, and M. Waycott. 2021. Susan Lynn Williams: The life of an exceptional scholar, leader, and friend (1951-2018). Estuaries and Coasts. https://doi.org/10.1007/s12237020-00886-y. 